\title{
HISTORY OF SCIENCE SOCIETY
}

\author{
www.hssonline.org
}

Join the Socifty and Receive the Leading Publication in the Field

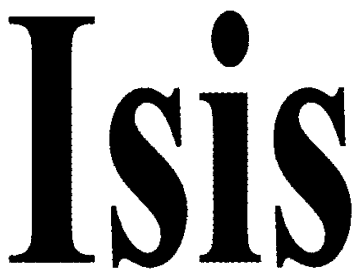

\section{AN INTERNATIONAL REVIEW DEVOTED TO THE HISTORY OF SCIENCE AND ITS CULTURAL INFLUENCES www.journals.uchicago.edu/Isis}

Margaret W. Rossiter; Editor: Published quarterly; includes the annual Current Bibliography. Founded in 1912, Isis is the oldest and largest circulating journal of the history of science. Each year subscribers receive some 848 pages featuring scholarly articles, research notes, documents, discussion, and news of the profession. Isis offers the largest reviewing service in the field, with review essays and some 300 shorter reviews assessing books from around the world.

Individual subscriptions to Isis and membership in the History of Science Society are concurrent. HSS members also receive the annual Current Bibliography, the HSS Newsletter, inclusion in the online membership directory, and reduced registration fees at regional and annual meetings. Your membership helps support a number of HSS programs to advance research and teaching in the history of science.

Annual subscription rates/membership dues: $\$ 59.00$ Individuals; $\$ 28.00$ Students: $\$ 201.00$ Institutions. Individual subscriptions to Isis and membership in the History of Science Society are concurrent. HSS membership is based on a calendar year. Outside USA and Canada, please add $\$ 14.00$ for Isis surface postage and aimail delivery of the Newsletter: Canadian residents, please add 7\%) GST. Visa and MasterCard accepted. To order, send check, purchase order. or complete charge card information (account no., expiration date, telephone no.. and signature) to the address below: ('redit card orders may be fased to (773) 753-0811. You may also order online using our secure server:

\section{University of Chicago Press} Journals Division, P.O. Box 37005, Chicago, IL 60637

Order online at www.journals.uchicago.edu/Isis 


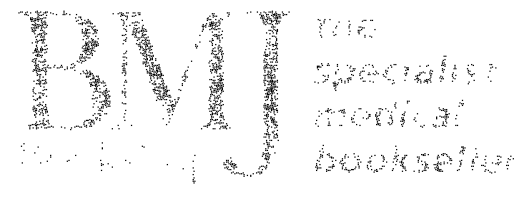

ofis

嗮:

\section{¿igigel $\underset{\text { Rhillips }}{\text { PhOOKS }}$}

Antiquarian books in the history of medicine and the health sciences.

Please send for my catalogue, or telephone for an appointment when in London.

5 BURLEIGH PLACE PUTNEY

LONDON SW15 6ES

Tel: 02087882664

Fax: 02087801989

e-mail: nigel@nigelphillips.com

\section{Antiquarian Books concerning Medicine, the Sciences \& Natural History}

Catalogues issued - Commissions \& Valuations undertaken Visitors welcome by Appointment

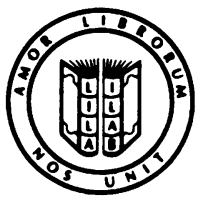

\section{MICHAEL PHELPS}

Allfreys House · Bolney Road Cowfold · West Sussex RH13 8AZ Telephone: +44 (0) 1403864049

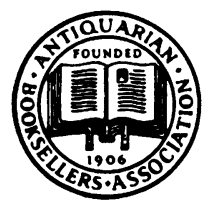

Fax: +44 (0) 1403864730 